\title{
Praperadilan Sebagai Sarana Kontrol Dalam Melindungi Hak Asasi Manusia (HAM) Tersangka
}

\author{
Rusman Sumadi \\ Dosen Tetap Fakultas Teknik Informatika Universitas Mitra Karya, Dosen Tidak Tetap MKWU \\ Universitas Bhayangkara Jakarta Raya \\ Email: dosen.cerdasbangsarsm@gmail.com
}

Received : 1 May 2021 | Revised : 22 May 2021 | Accepted : 2 June 2021 | Published : 10 Jun 2021

\begin{abstract}
Pretrial is an institution in the field of criminal law enforcement as regulated in Law number 8 of 1981 which handles someone who is arrested or detained, investigated, or prosecuted not in accordance with applicable legal regulations where this institution has the function of correcting actions taken by officials at both the investigation and prosecution levels. In practice, it often happens that the submission of pretrial applications by the suspect or his family or other parties on the power of the suspect regarding the legality of an arrest or detention, before the pretrial hearing is over, is invalidated, because the main criminal case has already started being tried. As a result, the suspect remains in custody, while the possibility that the pretrial will give a verdict that the arrest or detention is illegal. This is detrimental to the suspect, the image of the law and justice. The existence of commissioner judges in the Draft Criminal Procedure Code can provide more functions for pretrial institutions with various changes or expansion of their powers. Besides this expansion of authority, it is more important to protect the human rights of suspects in the future.
\end{abstract}

Keywords: pretrial, investigation, prosecution, suspect

\begin{abstract}
ABSTRAK
Praperadilan adalah sebagai suatu lembaga dibidang penegakan hukum pidana yang diatur di dalam Undang - undang nomor 8 Tahun 1981 yang menangani seseorang yang ditangkap ataupun ditahan, disidik, atau dituntut tidak sesuai dengan peraturan hukum yang berlaku dimana lembaga ini mempunyai fungsi mengkoreksi atas tindakan yang dilakukan oleh pejabat baik ditingkat penyidikan maupun ditingkat penuntutan. Dalam prakteknya sering terjadi, pengajuan permohonan praperadilan oleh tersangka atau keluarganya atau pihak lain atas kuasa tersangka mengenai sah tidaknya penangkapan atau penahanan, sebelum pemeriksaan praperadilan selesai menjadi gugur, karena perkara pidana pokok sudah mulai disidangkan. Sehingga berakibat tersangka tetap dalam tahanan, sedangkan kemungkinan praperadilan akan memberi putusan penangkapan atau penahanan tersebut adalah tidak sah. Ini merugikan tersangka, citra hukum dan keadilan. Keberadaan hakim komisaris dalam RUU KUHAP dapat lebih memberikan fungsi lembaga praperadilan dengan berbagai perubahan ataupun perluasan wewenangnya. Disamping perluasan wewenang tersebut hal yang lebih penting adanya perlindungan hak asasi terhadap tersangka di masa mendatang.
\end{abstract}

Kata Kunci: Praperadilan, penyidikan, penuntutan, tersangka 


\section{PENDAHULUAN}

Indonesia adalah negara yang berdasarkan hukum sebagaimana diatur dalam amandemen ketiga Pasal 1 Ayat (3) UUD 1945 yang berbunyi: "Negara Indonesia adalah negara hukum." Sebagai negara hukum, maka untuk menjalankan suatu negara dan perlindungan hak asasi manusia harus berdasarkan hukum. Kondisi ini menyebabkan peraturan perundang-undangan memegang peranan yang sangat strategis sebagai landasan dan strategi negara untuk mencapai tujuan sebagaimana yang telah ditentukan. Dalam hal menentukan suatu perbuatan yang dilarang atau tindak pidana dalam suatu peraturan perundang-undangan digunakan kebijakan hukum pidana. Hukum Acara Pidana berhubungan erat dengan adanya hukum pidana, maka dari itu merupakan suatu rangkaian peraturan yang memuat acara bagaimana badan-badan pemerintah yang berkuasa yaitu, kepolisian, kejaksaan, dan pengadilan harus bertindak guna mencapai tujuan negara dengan mengadakan hukum pidana. Tujuan dari Hukum Acara Pidana adalah mencari dan mendapatkan atau setidaktidaknya mendekati kebenaran material, ialah kebenaran yang selengkap-lengkapnya dari suatu perkara pidana dengan menerapkan ketentuan Hukum Acara Pidana secara jujur dan tepat.

Kalau ditelaah secara teliti isi ketentuan sebagaimana dimuat dalam KUHAP, maka sistem peradilan pidana Indonesia yang terdiri dari komponen Kepolisian, Kejaksaan, Pengadilan dan Lembaga Pemasyarakatan sebagai aparat penegak hukum, setiap komponen dari sistem tersebut seharusnya secara konsisten menjaga agar sistem dapat berjalan secara terpadu.

Demi untuk terlaksananya kepentingan pemeriksaan tindak pidana, undangundang memberikan kewenangan kepada penyidik dan penuntut umum untuk melakukan tindakan upaya paksa berupa penangkapan, penahanan, penyitaan dan sebagainya. Sesuai dengsan konteks ini maka Tindakan-tindakan penangkapan, penahanan, penggeledahan dan penyitaan haruslah dilakukan secara yuridis formil dengan bentuk tertulis sesuai kewenangan yang diberikan undang-undang. Menangkap dan menahan berkaitan dengan menghilangkan kemerdekaan. Mengeledah berkaitan dengan hak pribadi (privacy), menyita berkaitan dengan perampasan hak milik. Hak atas kemerdekaan, privacy dan milik merupakan hak asasi utama yang harus dilindungi dan dihormati. ${ }^{1}$ Upaya-upaya tersebut sebagian besar terdapat dan diatur dalam KUHAP, memang kenyataan ini cukup menggembirakan dengan demikian diharapkan akan dapat memberikan jaminan dan perlindungan terhadap hak asasi manusia, perlindungan terhadap harkat dan martabat manusia sebagaimana wajarnya dimiliki oleh suatu negara hukum, salah satu upaya tersebut adalah lembaga Praperadilan. Kalau kita teliti istilah yang dipergunakan oleh KUHAP "praperadilan" maka maksud dan artinya secara harfiah berbeda. Pra artinya sebelum, atau mendahului, berarti "praperadilan" sama dengan sebelum pemeriksaan disidang pengadilan (sebelum memeriksa pokok dakwaan Penuntut Umum). Praperadilan ${ }^{2}$ adalah sebagai suatu lembaga dibidang penegakan hukum pidana yang menangani seseorang yang ditangkap ataupun ditahan, disidik, atau dituntut tidak sesuai dengan peraturan hukum yang berlaku dimana lembaga ini mempunyai fungsi mengkoreksi atas tindakan yang dilakukan oleh pejabat baik ditingkat penyidikan maupun ditingkat penuntutan.

Isi Pasal 82 huruf d KUHAP menyatakan bahwa; dalam hal suatu perkara

\footnotetext{
${ }^{1}$ Lilik Mulyadi, Putusan Hakim dalam Hukum Acara Pidana (Teori, Praktik, Teknik Penyusunan dan Permasalahannya),PT Citra Aditya Bakti, Bandung, 2007, hlm. 8

2 "Praperadilan", Indonesia-p@igc.apc.org,17 Pebruari 2010
} 
sudah mulai diperiksa oleh pengadilan negeri sedangkan pemeriksaan mengenai permintaan kepada praperadilan belum selesai, maka permintaan tersebut gugur. Kalau proses praperadilan belum selesai, gugur atas dasar alasan teknis, karena perkara pidana pokok sudah mulai disidangkan, bukan atas alasan yang prinsipil, maka tujuan praperadilan menjadi kabur dan kehilangan makna.

Menurut Harjono Tjitrosoebono, pemeriksaan perkara pidana pokok oleh pengadilan seharusnya menunggu sampai selesainya pemeriksaan praperadilan, dan tidak sebaliknya proses peradilan menjadi gugur sebelum selesai, sehingga permasalahan hukum pada pemeriksaan seperti dimaksud Pasal 77 huruf a KUHAP : "Pengadilan Negeri berwenang untuk memeriksa dan memutus, sesuai dengan ketentuan yang diatur dalam Undang-undang ini, tentang sah atau tidaknya penangkapan, penahanan dan penghentian penuntutan.

Menjadi tidak terjawab, ini merugikan tersangka, citra hukum, dan keadilan. Dalam prakteksering terjadi, pengajuan permohonan praperadilan oleh tersangka atau keluarganya atau pihak lain atas kuasa tersangka mengenai sah tidaknya penangkapan atau penahanan, sebelum pemeriksaan praperadilan selesai menjadi gugur, karena perkara pidana pokok sudah mulai disidangkan. Sehingga berakibat tersangka tetap dalam tahanan, sedangkan kemungkinan praperadilan akan memberi putusan penangkapan atau penahanan tersebut adalah tidak sah.

Kecendrungan bahwa mayoritas kasus praperadilan "gugur ditengah jalan" sebelum diputus oleh hakim pengadilan dengan alasan sederhana yaitu materi pokok perkara tersebut telah disidangkan oleh pengadilan. Dalam beberapa contoh kasus misalnya Perkara praperadilan M.NASEH dengan nomor perkara 05/Pid.Pra/2009/PN.Bks dengan dugaan perampokan rumah warga, perkara ALI USMAN bin ALI ABIDIN dengan nomor perkara 06/Pid.Pra/2007/PN.Jkt Barat dengan dugaan penadahan hasil pencurian besi, serta Putusan Perkara No. 01/Pid.Pra/2011/PNSBB (Sumbawa Besar) HERI SAPTOAJI dengan dugaan pengelapan mobil kijang innova milik perusahaan ACC Mataram Finance, yang mana perkara-perkara tersebut diatas dinyatakan gugur oleh hakim Pengadilan Negeri ditengah-tengah proses acara peradilan.

Berdasarkan paparan diatas, ada dua problematika hukum yang dirumuskan sebagai masalah penelitian. Kedua problematika hukum tersebut adalah sebagai berikut. Pertama, Bagaimana fungsi lembaga praperadilan dalam kaitannya dengan Hak Asasi Manusia? Kedua, Bagaimana kebijakan hukum pidana dalam memformulasikan lembaga praperadilan sebagai sarana kontrol dalam melindungi Hak Asasi Manusia tersangka di masa mendatang?

\section{METODE PENELITIAN}

Ilmu Hukum adalah ilmu praktis-Normologis yang otoritatif.Objek kajian Ilmu Hukum adalah norma-norma hukum positif yang berlaku dalam suatu negara (masyarakat) beserta dengan asas-asas hukum dan doktrin-doktrin hukum.Ilmu Hukum bertujuan menyusun argumentasi hukum untuk menghasilkan pendapat hukum dalam rangka membenarkan atau menyangkal pendapat hukum. Dalam bingkai pemahaman seperti dikemukakan di atas, metode penelitian hukum yang dalam penelitian ini adalah metode penelitian yuridis-normatif. Objek kajian penelitian adalah bahan-bahan hukum yang terdiri atas bahan hukum primer, sekunder dan tersier. 


\section{PEMBAHASAN}

Tegaknya HAM selalu mempunyai hubungan korelasional positif dengan tegaknya negara hukum. Sehingga dengan dibentuknya KOMNAS HAM dan Pengadilan HAM akan lebih menyegarkan iklim penegakkan hukum yang sehat. Artinya kebenaran hukum dan keadilan harus dapat dinikmati oleh setiap warganegara Indonesia. Disadari atau tidak, dengan adanya political will dari pemerintah terhadap penegakkan HAM, hal itu akan berimplikasi terhadap budaya politik yang lebih sehat dan proses demokratisasi yang lebih cerah. Dan harus disadari pula bahwa kebutuhan terhadap tegaknya HAM dan keadilan itu memang memerlukan proses dan tuntutan konsistensi politik. Begitu pula keberadaan budaya hukum dari aparat pemerintah dan tokoh masyarakat merupakan faktor penentu (determinant) yang mendukung tegaknya HAM.

Kenyataan menunjukkan bahwa masalah HAM di Indonesia selalu menjadi sorotan tajam dan bahan perbincangan terus-menerus, baik karena konsep dasarnya yang bersumber dari UUD 1945 maupun dalam realita praktisnya dilapangan penuh dengan pelanggaran-pelanggaran. Sebab-sebab pelanggaran HAM antara lain adanya arogansi kewenangan dan kekuasaan yang dimiliki seorang pejabat yang berkuasa.

Issue mengenai HAM di Indonesia bergerak dengan cepat dan dalam jumlah yang sangat mencolok. Gerak yang cepat tersebut terutama karena memang telah terjadi begitu banyak pelanggaran HAM, mulai dari yang sederhana sampai pada pelanggaran HAM berat (gross human right violation). Pelanggaran HAM yang berat menurut Pasal 7 UU No.26 Tahun 2000 meliputi kejahatan genosida (the crime of genocide) dan kejahatan terhadap kemanusiaan (crime against humanity). Kejahatan genosida adalah setiap perbuatan yang dilakukan dengan maksud untuk menghancurkan atau memusnahkan seluruh atau sebagian kelompok bangsa, ras, kelompok etnis, kelompok agama, dengan cara:

1. Membunuh anggota kelompok

2. Mengakibatkan penderitaan fisik atau mental yang berat terhadap anggotaanggota kelompok.

3. Menciptakan kondisi kehidupan kelompok yang akan mengakibatkan kemusnahan secara fisik baik seluruh atau sebagiannya.

4. Memaksakan tindakan - tindakan yang bertujuan mencegah kelahiran di dalam kelompok.

Sedangkan kejahatan terhadap kemanusiaan adalah salah satu perbuatan yang dilakukan sebagai bagian dari serangan yang meluas yang diketahui bahwa serangan tersebut ditujukan secara langsung terhadap penduduk sipil berupa pembunuhan, pemusnahan, perbudakan, pengusiran, perampasan kemerdekaan, penyiksaan, perkosaan, penganiyaan, serta penghilangan orang secara paksa.

Seperti diketahui, di Indonesia telah terjadi banyak kasus yang diindikasikan sebagai pelanggaran HAM berat, terutama kasus kekerasan struktural yang melibatkan aparat negara (polisi dan militer) dengan akibat jatuhnya korban dari kalangan penduduk sipil. Di antara sederetan kasus yang mendapat sorotan tajam dunia ainternasional adalah kasus DOM di Aceh, Tanjung Priuk, Timor - Timur pasca jejak pendapat, tragedi Semanggi dan Trisakti. Pelanggaran - pelanggaran tersebut dinilai cukup serius dan bukanlah sebagai kejahatan biasa, tetapi merupakan kejahatan terhadap kemanusiaan (crime against humanity). 
Munculnya berbagai kasus pelanggaran HAM berat telah melahirkan kesadaran kolektif tentang perlunya perlindungan HAM melalui instrumen hukum dan kerja institusi penegak hukumnya. Banyak kasus - kasus pelanggaran HAM berat atau yang mengandung unsur adanya pelanggaran HAM yang selama ini tidak tersentuh oleh hukum, sebagai akibat dari bergulirnya reformasi secara perlahan tetapi pasti mulai diajukan ke lembaga peradilan. Lembaga peradilan, dalam hal ini Pengadilan HAM, merupakan forum paling tepat untuk membuktikan kebenaran tuduhan tuduhan adanya pelanggaran HAM di Indonesia. Pasal 104 ayat (1) UU No.39 Tahun 1999 secara tegas menyatakan bahwa untuk mengadili pelanggaran HAM yang berat dibentuk Pengadilan HAM di lingkungan Peradilan Umum. Hukum acara yang berlaku atas perkara pelanggaran HAM yang berat menurut Pasal 10 UU No.26 Tahun 2000, dilakukan berdasarkan ketentuan hukum acara pidana, kecuali ditentukan lain dalam Undang-Undang ini.

HAM adalah persoalan yang bersifat universal, setiap negara mempunyai sejarah perjuangan dan perkembangan HAM yang berbeda, oleh karena itu konsepsi dan implementasi HAM dari suatu negara tidak dapat disamaratakan. Adanya HAM menimbulkan konsekwensi adanya kewajiban asasi, dimana keduanya berjalan secara paralel dan merupakan satu kesatuan yang tidak dapat dipisahkan. Pengabaian salah satunya akan menimbulkan pelanggaran HAM. Perkembangan dan perjuangan dalam mewujudkan tegaknya HAM di Indonesia terutama terjadi setelah adanya perlawanan terhadap penjajahan bangsa asing, sehingga tidak bisa dilihat sebagai pertentangan yang hanya mewakili kepentingan suatu golongan tertentu saja, melainkan menyangkut kepentingan bangsa Indonesia secara utuh.

Dewasa ini, meskipun banyak kasus pelanggaran HAM berat di Indonesia, tetapi secara umum implementasi HAM di Indonesia, baik menyangkut perkembangan dan penegakkan HAM mulai menampakkan tanda - tanda kemajuan. Hal ini terlihat dengan adanya regulasi hukum HAM melalui peraturan perundang - undangan. Dibentuknya Pengadilan HAM di Indonesia patut disambut gembira, karena diharapkan dapat meningkatkan citra baik Indonesia di mata Internasional, bahwa Indonesia mempunyai komitmen dan polical will untuk menyelesaikan berbagai kasus pelanggaran HAM berat. Seiring dengan itu upaya penegakkan HAM di Indonesia diharapkan mengalami peningkatan yang cukup signifikan.

Dalam ketentuan Kitab Undang-Undang Hukum Acara Pidana (KUHAP) baik dalam Bab VI Tentang Tersangka dan Terdakwa maupun Bab VII tentang Bantuan Hukum, tidak nampak sama sekali hak seorang tersangka untuk menolak atau membela kepentingannya, misalnya menolak menjawab pertanyaan pejabat penyidik sebelum didampingi penasihat hukum. Praperadilan ini benar-benar merupakan suatu proses pemeriksaan singkat, oleh karena sejak diterimanya permulaan sidang praperadilan oleh Pengadilan Negeri, selambat-lambatnya dalam waktu sepuluh hari, hakim harus sudah menjatuhkan putusannya. Dari mekanisme kerja lembaga praperadilan ini, tampak bahwa lembaga tersebut merupakan alat penyaring terakhir bagi proses penyidikan, penangkapan dan penahanan atas seorang tersangka sebelum meningkat pada tingkat pemeriksaan di muka sidang pengadilan.

Dari uraian di atas dapatlah ditarik benang merah bahwa pemeriksaan perkara pidana berdasarkan KUHAP dimulai dari pemeriksaan pendahuluan yang dilakukan oleh Penyidik dan Penuntut Umum, pemeriksaan di sidang pengadilan dan pembinaan melalui lembaga pemasyarakatan. Kalau kita teliti istilah yang dipergunakan oleh KUHAP "praperadilan" maka maksud dan artinya secara harfiah berbeda. Pra artinya 
sebelum, atau mendahului, berarti "praperadilan" sama dengan sebelum pemeriksaan di sidang Pengadilan (sebelum memeriksa pokok dakwaan Penuntut Umum).

Di Eropa dikenal lembaga semacam praperadilan, tetapi fungsinya memang benar-benar melakukan pemeriksaan pendahuluan. Jadi fungsi Hakim Komisaris (Rechter commisaris) di negeri Belanda dan Judge d'Instruction di Perancis benarbenar dapat disebut Praperadilan, karena selain menentukan sah tidaknya penangkapan, penahanan, penyitaan, juga melakukan pemeriksaan pendahuluan atas suatu perkara. Menurut Oemar Seno Adji, lembaga rechter commisaris (hakim yang memimpin pemeriksaan pendahuluan) muncul sebagai perwujudan keaktifan hakim, yang di Eropa Tengah mempunyai posisi penting yang mempunyai kewenangan untuk menangani upaya paksa (dwangmiddelen), penahanan, penyitaan, penggeledahan badan, rumah, dan pemeriksaan surat - surat. Hakim komisaris selain misalnya berwenang untuk menilai sah tidaknya suatu penangkapan, penahanan seperti praperadilan, juga sah atau tidaknya suatu penyitaan yang dilakukan oleh jaksa.

Menurut KUHAP tidak ada ketentuan dimana hakim praperadilan melakukan pemeriksaan pendahuluan atau memimpinnya. Hakim praperadilan tidak melakukan penggeledahan, penyitaan dan seterusnya yang bersifat pemeriksaan pendahuluan. Ia tidak pula menentukan apakah suatu perkara cukup alasan ataukah tidak untuk diteruskan ke pemeriksaan sidang pengadilan. Penentuan diteruskan ataukah tidak suatu perkara tergantung kepada jaksa penuntut umum. Bahkan tidak ada kewenangan hakim praperadilan untuk menilai sah tidaknya suatu penggeledahan dan penyitaan yang dilakukan oleh jaksa dan penyidik. Padahal kedua hal itu sangat penting dan merupakan salah satu asas dasar hak asasi manusia. Penggeledahan yang tidak sah merupakan pelanggaran terhadap ketentraman rumah tempat kediaman seseorang. Begitu pula penyitaan yang tidak sah merupakan pelanggaran serius terhadap hak milik orang.

Praperadilan merupakan salah satu lembaga baru yang diperkenalkan sejak adanya Kitab Undang-Undang Hukum Acara Pidana (KUHAP) di tengah-tengah kehidupan penegakan hukum. Praperadilan dalam Undang-Undang Nomor 8 Tahun 1981 tentang KUHAP ditempatkan dalam Bab X, Bagian Kesatu, sebagai salah satu bagian ruang lingkup wewenang mengadili bagi Pengadilan Negeri, Ditinjau dari segi struktur dan susunan peradilan, Praperadilan bukan lembaga pengadilan yang berdiri sendiri. Bukan pula sebagai instansi tingkat peradilan yang mempunyai wewenang memberi putusan akhir atas suatu kasus peristiwa pidana. Praperadilan hanya suatu lembaga baru yang ciri dan eksistensinya:

1. Berada dan merupakan kesatuan yang melekat pada Pengadilan Negeri, dan sebagai lembaga pengadilan, hanya dijumpai pada tingkat Pengadilan Negeri sebagai satuan tugas yang tidak terpisah dari Pengadilan Negeri, dengan demikian, Praperadilan bukan berada diluar atau disamping maupun sejajar dengan Pengadilan Negeri, tetapi hanya merupakan divisi dari Pengadilan Negeri,

2. Administratif yustisial, personil, peralatan dan finansial bersatu dengan Pengadilan Negeri dan berada di bawah pimpinan serta pengawasan dan pembinaan Ketua Pengadilan Negeri, tata laksana fungsi yustisialnya 
merupakan bagian dari fungsi yustisial Pengadilan Negeri itu sendiri. ${ }^{3}$

Dari gambaran diatas, eksistensi dan kehadiran Praperadilan bukan merupakan lembaga tersendiri, tetapi hanya merupakan pemberian wewenang dan fungsi baru yang dilimpahkan KUHAP kepada setiap pengadilan negeri, sebagai wewenang dan fungsi tambahan Pengadilan Negeri yang telah ada selama ini.

Selama ini wewenang dan fungsi Pengadilan Negeri mengadili dan memutus perkara pidana dan perkara perdata sebagai tugas pokok, maka terhadap tugas pokok tadi diberi tugas tambahan untuk menilai sah atau tidaknya penangkapan, penahanan, penyitaan, penghentian penyidikan atau penghentian penuntutan yang dilakukan penyidik atau penuntut umum yang wewenang pemeriksaannya diberikan kepada Praperadilan. Hal tersebut terlihat dalam Pasal 1 butir 10 KUHAP yang menegaskan:

Praperadilan adalah wewenang Pengadilan Negeri untuk memeriksa dan memutus:

a) sah atau tidaknya suatu penangkapan atau penahanan,

b) sah atau tidaknya penghentian penyidikan atau penghentian penuntutan permintaan ganti rugi atau rehabilitasi oleh tersangka atau keluarganya atau pihak lain kuasanya yang perkaranya tidak diajukan ke pengadilan.

Upaya kontrol yang diperlukan dalam hal adanya pembatasan Hak Asasi dimaksud telah disediakan dalam KUHAP melalui Lembaga Praperadilan, namun dalam pelaksanaannya masih banyak adanya kekurangan-kekurangan yang menyebabkan belum terlindunginya Hak Asasi Manusia. Perlindungan Hak Asasi Manusia yang masih kurang memadai dalam proses Praperadilan terlihat dalam ketentuan Pasal 82 ayat (1) huruf d KUHAP yang berbunyi sebagai berikut:

"Dalam hal suatu perkara sudah mulai diperiksa oleh pengadilan negeri, sedangkan pemeriksaan mengenai permintaan kepada praperadilan belum selesai, maka permintaan tersebut gugur"

Dengan memperhatikan ketentuan Pasal 82 ayat (1) huruf d tersebut dihubungkan dengan rasa keadilan dan perlindungan Hak Asasi Manusia, telah terjadi pengabaian hak-hak asasi manusia sehingga diperlukan adanya pembaharuan hukum terkait dalam hal praperadilan, baik dari sudut struktural maupun substansial yang nantinya diharapkan dengan adanya pembaharuan dimaksud, tolak ukurnya lebih menitik beratkan pada hal keadilan dalam masyarkat dan perlindungan Hak Asasi Manusia.

Dalam hal pengaturan suatu lembaga praperadilan diperlukan suatu strategi yang baik dan efektif dalam suatu kebijakan yang diambil oleh perumus kebijakan. Kebijakan tersebut dapat dituangkan dalam bentuk peraturan perundang-undangan. Dalam menyusun suatu peraturan perundang-undangan yang baik, perlu dipertimbangkan bagaimana mencapai keseimbangan antara kepastian hukum dan keadilan, kepentingan individu dan masyarakat serta tidak terlepas dari upaya pemerintah dan masyarakat dalam rangka perlindungan hak asasi manusia dibidang hukum pidana khususnya dalam hal perlindungan hak asasi manusia dari upaya paksa yang dilakukan oleh aparat penegak hukum. Pembaharuan hukum acara pidana juga

3 M.Yahya Harahap, Pembahasan Permasalahan dan Penerapan KUHAP Pemeriksaan Sidang Pengadilan, Banding, Kasasi dan Peninjauan Kembali, Edisi Kedua, Sinar Grafika, Jakarta,2006, hlm 1 
dimaksudkan untuk lebih memberikan kepastian hukum, penegakan hukum, ketertiban hukum, keadilan masyarakat dan perlindungan hukum serta hak asasi manusia baik bagi tersangka demi terselenggarannya negara hukum. Perlindungan hak asasi manusia dalam hal dilakukannya upaya paksa, membutuhkan suatu kebijakan hukum pidana yang mencari akar penyebab (solusi) dari timbulnya pelanggaran atas hak-hak tersebut, dan juga diperlukan upaya penal yang terdiri atas kebijakan formulasi, aplikasi dan reformasi dalam hal perlindungan hak-hak asasi manusia tersangka.

Dalam sistem peradilan pidana yang lazim, selalu melibatkan dan mencakup sub sistem dengan ruang lingkup masing-masing proses peradilan pidana sebagai berikut :

1. Kepolisian dengan tugas utama menerima laporan dan pengaduan dari publik manakala terjadi tindak pidana, melakukan penyelidikan dan penyidikan tindak pidana, melakukan penyaringan terhadap kasus-kasus yang memenuhi syarat untuk diajukan ke kejaksaan, melaporkan hasil penyidikan kepada kejaksaan dan memastikan dilindunginya para pihak yang terlibat dalam proses peradilan pidana.

2. Kejaksaan dengan tugas pokok menyaring kasus - kasus yang layak diajukan ke Pengadilan, mempersiapkan berkas penuntutan, melakukan penuntutan dan melaksanakan putusan pengadilan.

3. Pengadilan yang berkewajiban untuk menegakkan hukum dan keadilan, melindungi hak-hak tersangka, terdakwa, saksi dan korban dalam proses peradilan pidana, melakukan pemeriksaan kasus - kasus secara efisien dan efektif, memberikan putusan yang adil dan berdasarkan hukum, dan menyiapkan persidangan sehingga publik dapat berpartisipasi dan melakukan penilaian terhadap proses peradilan ditingkat ini.

4. Lembaga Pemasyarakatan yang berfungsi untuk menjalankan putusan pengadilan yang merupakan pemenjaraan, memastikan perlindungan hak-hak narapidana, menjaga agar kondisi LP memadai untuk menjalankan pidana setiap narapidana, melakukan upaya-upaya untuk memperbaiki narapidana, mempersiapkan narapidana untuk kembali ke masyarakat.

5. Pengacara dengan fungsi melakukan pembelaan bagi klien, dan menjaga agar hak-hak klien dipenuhi dalam proses peradilan pidana.

Dalam praktek, sering terjadi bahwa pengajuan tuntutan Praperadilan oleh tersangka atau keluarganya mengenai tidak sahnya penangkapan dan atau penahanan atas diri tersangka, sebelum pemeriksaan Praperadilan selesai, perkaranya sudah menjadi gugur, karena perkara pidana pokok sudah mulai disidangkan, sehingga berakibat tersangka tetap dalam tahanan, sedangkan mungkin Praperadilan akan memberikan keputusan tidak sahnya penangkapan dan atau penahanan.

Sistem peradilan seharusnya menjamin adanya keputusan hukum yang tuntas yang tidak dengan sistem gugur tersebut. Sistem hukum yang sesuai dengan asas "duo proccess of law" harus menjamin proses Praperadilan sampai selesai hingga terdapat keputusan yang tidak dapat diganggu gugat lagi. Dan pemeriksaan perkara pidana pokok oleh pengadilan seharusnya menunggu sampai selesainya pemeriksaan oleh Praperadilan, dan tidak sebaliknya proses Praperadilan menjadi gugur sebelum selesai , sehingga dengan demikian permasalahan hukum dalam pemeriksaan pendahuluan seperti yang dimaksud dalam Pasal 77 KUHAP menjadi tidak terjawab, yang merugikan tersangka dan merugikan citra hukum dan keadilan. :Putusan Praperadilan 
yang menyatakan gugur akibat dari mulai diperiksanya perkara pokok terhadap perbuatan yang didakwakan kepada terdakwa, maka pemeriksaan perkara praperadilan belum memeriksa materi pokok dari permohonan praperadilan tersebut dalam arti hakim yang memeriksa permohonan praperadilan belum pada tahap mempertimbangkan apakah materi yang dijadikan obyek praperadilan telah sesuai dengan prosedur hukum atau sebaliknya.

Dengan adanya putusan gugur tersebut yang mana belum diperiksanya obyek praperadilan, maka tertutup kemungkinan bagi pemohon untuk melakukan upaya hukum atas putusan tersebut, dimana upaya hukum tersebut sangatlah penting bagi pemohon untuk mengetahui keabsahan dari tindakan hukum (penangkapan dan atau penahanan) yang dilakukan oleh pejabat tertentu berdasarkan kewenangannya terhadap diri tersangka. Seharusnya ada upaya hukum yang memberikan perlindungan hukum bagi mereka yang ditangkap, ditahan ataupun dihentikan penyidikan dan penuntutannya dimana perkara pokoknya telah diperiksa disidang pengadilan, apabila hal tersebut tidak dilakukan oleh pembuat undang-undang maka akan terjadi tindakan kesewenangwenangan oleh pejabat yang melakukan hal-hal tersebut diatas.

Tindakan sewenang-wenang tersebut akan kerap terjadi dengan alasan apabila terjadi permohonan praperadilan baik terhadap penyidik maupun Penuntut Umum, maka kedua pejabat tersebut dapat dengan leluasa melakukan upaya pelimpahan perkara ke Pengadilan Negeri dengan harapan akan dilakukan pemeriksaan terhadap perkara tersebut yang berakibat gugurnya permohonan praperadilan tersebut.

Putusan praperadilan tidak dapat dimintakan banding, artinya sudah mempunyai kekuatan hukum tetap, kecuali putusan yang menetapkan tidak sahnya penghentian penyidikan atau penuntutan, yang untuk itu dapat dimintakan putusan akhir ke Pengadilan Tinggi dalam daerah hukum yang bersangkutan. Putusan praperadilan juga tidak dapat dikasasi, apabila dilakukan upaya kasasi, maka permohonan kasasi tersebut dinyatakan tidak dapat diterima. Alasannya karena "keharusan cepat" dari perkara-perkara praperadilan tidak akan terpenuhi kalau masih dimungkinkan pemeriksaan kasasi.

Selain itu wewenang pengadilan negeri yang dilakukan oleh praperadilan ini dimaksudkan sebagai wewenang pengawasan secara horisontal dari pengadilan negeri dan bahwa juga pasal 244 KUHAP tidak memungkinkan pemeriksaan kasasi atas putusan-putuasn praperadilan, karena pasal ini mengenai putusan perkara pidana, dan perkara pidana yang dimaksud jelas perkara-perkara pidana yang telah benar-benar diperiksa dan diputus pengadilan tinggi atau pengadilan lain selain Mahkamah Agung, yang menurut hukum acara pidana baik pihak-pihak dalam perkara maupun acaranya berbeda sifat dan kedudukannya dari pihak-pihak dalam permintaan pemeriksaan praperadilan.

Dalam praktek persoalan mengenai praperadilan sering terjadi dan kadangkadang masih menjadi permasalahan karena tidak adanya persepsi dan penafsiran yang seragam dan hal itu terjadi karena KUHAP tidak mengaturnya. Mengenai kasus praperadilan yang amarnya menyatakan penyitaan yang dilakukan oleh penyidik tidak sah dan memerintahkan penyidik mengembalikan barang yang telah disita kepada yang berhak.

Putusan tersebut sebenarnya tidak dapat dilakukan upaya hukum kasasi. Namun penyidik bersikukuh hendak mengajukan kasasi dengan berpedoman bahwa pengadilan negeri tidak berwenang menolak kasasi, maka akhirnya permohonan kasasi 
tersebut diterima. Terhadap hal tersebut disarankan agar sikap Ketua Pengadilan Negeri untuk menerima dan meneruskan permohonan dimaksud kepada Mahkamah Agung yang akan nantinya mempertimbangkan permohonan itu.

Diperlukan adanya kebijakan dibidang sistem peradilan pidana, apabila diajukan permohonan praperadilan oleh pihak yang merasa dirugikan akibat dari tindakan pejabat baik penyidikan maupun penuntutan, dimana kebijakan tersebut dapat berupa amandemen Undang-Undang Nomor 8 Tahun 1981 tentang KUHAP dengan jalan menambah ketentuan apabila dilakukan permohonan praperadilan, seharusnya perkara pokok tidak dilimpahkan ke Pengadilan Negeri sebelum diputuskan permohonan praperadilan ini. Hal ini bertujuan memberikan perlindungan hukum dan kepastian hukum terhadap tersangka yang dikenai tindakan penangkapan dan atau penahanan oleh pejabat yang berwenang dimana tindakan pejabat tersebut akan dinilai atau dikontrol oleh lembaga praperadilan melalui putusannya yang mempertimbangkan keabsahan dari tindakan pejabat dimaksud. Sehingga nantinya tidak ada putusan praperadilan yang serta merta dinyatakan gugur akibat mulai diperiksanya perkara pidana pokok terhadap tersangka.

Masalah kepastian hukum menyangkut masalah bentuk dari hukum. Bentuk hukum yang tertulis disebut hukum undang-undang dan bentuk hukum yang tidak tertulis disebut hukum adat dan hukum kebiasaan. Bahwa hukum undang-undang yang karena bentuknya tertulis lebih banyak memberikan kepastian hukum. Kepastian hukum mempunyai dua segi sebagai berikut:

1. Dapat ditentukannya hukum dalam hal-hal yang kongkrit.

2. Kepastian hukum berarti keamanan hukum artinya perlindungan bagi para pihak terhadap kesewenang-wenangan ${ }^{4}$

Baik dalam undang-undang lama ataupun undang-undang baru, praperadilan termasuk yang tidak dapat dimohonkan kasasi, tetapi dalam beberapa putusan Mahkamah Agung yang menerima permohonan kasasi praperadilan baik dari sudut "begrip" putusan hakim maupun tujuan atau fungsi praperadilan memang secara doktriner harus ada pembatasan upaya hukum praperadilan. Tetapi hukum atau pranata hukum bukan sekedar pengertian, apalagi pengertian normatif. Hukum harus dikaji dengan tujuan umum dan manfaat umum. Pembatasan upaya hukum praperadilan harus diterobos apabila:

1. Praperadilan tersebut sedang digunakan untuk menghambat suatu proses peradilan

2. Praperadilan sedang digunakan untuk mencegah atau menghindari terwujudnya rasa keadilan

3. Praperadilan sedang dimanfaatkan oleh Majelis sebagai tempat persembunyian keberpihakan.

Penolakan yang semata-mata karena alasan normatif dapat menurunkan citra Mahkamah Agung yang tidak responsif terhadap tuntutan obyektif masyarakat. Dari uraian diatas ingin ditegaskan bahwa reformasi hukum tidak hanya berupa pembaharuan Undang-Undang atau substansi hukum tetapi juga pembaharuan struktur hukum dan pembaharuan budaya hukum yang termasuk didalamnya juga pembaharuan etika hukum dan ilmu hukum. Bahkan dalam situasi krisis saat ini yang

\footnotetext{
${ }^{4}$ Bachsan Mustafa, Sistem Hukum Administrasi Negara Indonesia, PT Citra Aditya Bakti, Bandung, 2001, hlm 34.
} 
terpenting justru pembaharuan aspek immateriil dari hukum yaitu pembaharuan budaya hukum, etika moral hukum dan ilmu pendidikan hukum. Aspek immateriil dari pembaharuan hukum inilah yang seyogyanya lebih diutamakan apabila sasaran utamanya adalah penegakan keadilan.

Terlebih hakekat pembaharuan/pembangunan hukum bukan terletak pada aspek formal dan lahiriah (seperti terbentuk Undang-Undang baru, struktur kelembagaan dan mekanisme/prosedur baru, bertambahnya bangunan dan sarana/prasarana lainnya yang serba baru) melainkan justru terletak pada aspek immateriil ini, yakni membangun budaya dan nilai-nilai kejiwaan dari hukum. ${ }^{5}$ Kualitas penegakan hukum yang dituntut masyarakat saat ini bukan sekedar kualitas formal, tetapi terutama kualitas penegakan hukum secara materiil/substansial seperti terungkap dalam beberapa isu sentral yang dituntut masyarakat, antara lain:

1. adanya perlindungan Hak Asasi Manusia (HAM)

2. tegaknya nilai kebenaran

3. tidak adanya penyalahgunaan kekuasaan / kewenangan

4. bersih dari praktik "favoritisme" (pilih kasih), KKN dan mafia peradilan

5. terwujudnya kekuasaan kehakiman / penegakan hukum yang merdeka, dan tegaknya kode etik / kode profesi.

6. adanya penyelenggaraan pemerintahan yang bersih dan berwibawa, kualitas subtansi yang terungkap dalam berbagai isu sentral diatas, jelas lebih menekankan pada aspek immateriil / non fisik dari pembangunan masyarakat / nasional.

Pembangunan nasional tidak hanya bertujuan meningkatkan kualitas masyarakat (lingkungan hidup dan kehidupan) secara materiil, tetapi juga secara immateriil. Kehidupan makmur dan berkecukupan secara materiil saja bukanlah jaminan untuk adanya lingkungan kehidupan yang menyenangkan dan berkualitas.

\section{KESIMPULAN}

Tujuan yang hendak dicapai dalam upaya penegakan hukum dalam proses peradilan pidana adalah mengurangi keinginan melakukan pelanggaran aturan pidana, serta sekaligus memenuhi rasa keadilan masyarakat. Sistem peradilan pidana sebagai suatu sistem pada dasarnya merupakan suatu open system, dalam pengertian sistem peradilan pidana adalah sistem yuang terpadu, jika dilihat secara normatif (peraturan perundang-undangan) dapat dijelaskan sebagai berikut:

1. Kepolisian; mekanisme kontrolnya adalah terkait dengan Praperadilan, untuk mengawasi penangkapan, penahanan dan penghentian penyidikan tidak sah.

2. Kejaksaan; mekanisme kontrolnya melalui Praperadilan untuk mengawasi penghentian penuntutan yang tidak sah.

3. Pengadilan; mekanisme kontrolnya melalui upaya hukum biasa dan luar biasa.

4. Lembaga Pemasyarakatan; mekanisme kontrolnya melalui hakim pengawas 5 Barda Nawawi Arief, Masalah Penegakan Hukum dan Kebijakan Hukum Pidana dalam
Penanggulangan Kejahatan, Jakarta, Kencana, Ed 1, Cet 2, 2008, hlm 6 
dan pengamatan.

5. Penasihat Hukum; mekanismenya kontrolnya melalui pengadilan dan organisasi yang membawahi penasihat hukum itu sendiri.

Dasar pijakan dari sistem peradilan pidana adalah tersebar dalam berbagai peraturan perundang-undangan yang ada dibidang hukum pidana adalah sebagai berikut :

a. Lembaga Kepolisian diatur dalam Undang-Undang Nomor 2 Tahun 2002, asas yang menjadi dasar sistem peradilan pidana adalah asas menjunjung tinggi HAM, asas legalitas, asas preventif.

b. Lembaga Kejaksaan diatur dalam Undang-Undang Nomor 16 Tahun 2004, asas yang menjadi dasar sistem peradilan pidana. Lembaga Kejaksaan adalah satu dan tidak terpisah-pisahkan, asas keseimbangan antara publik dan pemerintah, asas oportunitas.

c. Lembaga Pengadilan diatur dalam Undang-Undang Nomor 4 Tahun 2004, serta Undang-Undang Nomor 2 Tahun 1986 jo Undang-Undang Nomor 8 Tahun 2004, asas yang menjadi dasar sistem peradilan pidana adalah asas sederhana, cepat, dan biaya murah, asas mandiri dan tidak memihak, persamaan dimuka hukum, legalitas, praduga tak bersalah, terbuka untuk umum, perlindungan HAM, Due Process of Law, nebis in idem.

d. Lembaga Pemasyarakatan, diatur dalam Undang-Undang Nomor 12 Tahun 1995, asas yang menjadi dasar sistem peradilan pidana adalah asas pengayoman, persamaan perlakuan dan pelayanan, pendidikan, pembimbingan dan penghormatan HAM.

e. Lembaga Profesi Advokat, diatur dalam Undang-Undang Nomor 18 Tahun 2003 tentang advokat, dalam Undang-Undang ini dijelaskan bahwa advokat berstatus sebagai penegak hukum, bebas, mandiri untuk terselenggaranya peradilan yang jujur, adil dan memiliki kepastian hukum bagi semua pencari keadilan dalam menegakkan hukum, kebenaran, keadilan dan HAM.

Negara Indonesia adalah negara hukum yang berarti bahwa negara Indonesia menjunjung tinggi hak asasi manusia dan menjamin segala warga negaranya bersamaan kedudukannya di dalam hukum dan pemerintahan, serta wajib menjunjung hukum dan pemerintahan itu dengan tidak ada kecualinya. Hak asasi manusia dengan negara hukum tidak dapat dipisahkan, justru berpikir secara hukum berkaitan dengan ide bagaimana keadilan dan ketertiban dapat terwujud. Dengan demikian pengakuan dan pengukuhan negara hukum salah satu tujuannya melindungi hak asasi manusia, berarti hak dan sekaligus kebebasan perseorangan diakui, dihormati dan dijunjung tinggi.

\section{SARAN}

Keberadaan hakim komisaris dalam RUU KUHAP dapat lebih memberikan fungsi lembaga praperadilan dengan berbagai perubahan ataupun perluasan wewenangnya. Disamping perluasan wewenang tersebut hal yang lebih penting adanya perlindungan hak asasi terhadap tersangka dimasa mendatang. Yang paling utama adalah moralitas manusia yang ditunjuk sebagai pejabat dalam sistem peradilan pidana yang telah ditetapkan. Untuk itu lembaga praperadilan tetap diterapkan dalam 
rancangan undang-undang tentang hukum acara pidana dengan rumusan lebih kongkret dan lebih mengutamakan kepentingan tersangka. Untuk masa mendatang diperlukan suatu lembaga praperadilan yang dapat melakukan upaya kontrol terhadap tindakan aparat penegak hukum khususnya dalam tahap pemeriksaan pendahuluan.

Upaya kontrol tersebut lebih menekankan pada asas kesimbangan perlindungan hak asasi manusia bagi tersangka. Untuk menciptakan lembaga praperadilan yang dimaksud perlu diadakan pembaharuan / kebijakan dibidang hukum pidana yang meliputi :

1. Pembaharuan dari segi substansi dapat dilihat dari kebijakan memperluas ataupun menambah kewenangan lembaga praperadilan tersebut berupa kewenangan menetapkan sah atau tidaknya penahanan, menangguhkan penahanan suatu perkara layak atau tidak layak untuk dilakukan penuntutan ke Pengadilan.

2. Pembaharuan dari segi struktur dari suatu lembaga praperadilan yang berdiri sendiri dan terpisah dari kantor Pengadilan Negeri.

3. Pembaharuan dari segi budaya hukum dapat berupa memberikan pemahaman ataupun pendidikan hukum kepada masyarakat (pencari keadilan) mengenai peranan praperadilan sebagai sarana kontrol dari aparat penegak hukum (penyidik maupun Penuntut Umum) untuk menjamin perlindungan hukum.

\section{DAFTAR PUSTAKA}

\section{A. Buku}

Ahmad Syahrizal, Peradilan Konstitusi Suatu Studi Tentang Adjudikasi Konstitusional Sebagai Mekasnisme Penyelesaian Sengketa Normatif, Pradnya Paramita, Jakarta, 2006.

Agung Susanto, Hukum Acara Perkara Konstitusi, Mandar Maju, Bandung, 2006

Andi Hamzah, Hukum Acara Pidana Indonesia, Sinar Grafika, Jakarta, 2000.

Hukum Acara Pidana Indonesia, Edisi Revisi Sinar Grafika, Jakarta, 2008

Bachsan Mustafa, Sistem Hukum Administrasi Negara Indonesia, PT Citra Aditya Bakti, Bandung, 2001.

Bambang Waluyo, Penelitian Hukum Dalam Praktek, Sinar Grafika, Jakarta, 2002

Banda Nawawi Arief, Masalah Penegakan Hukum dan Kebijakan Hukum Pidana dalam Penanggulangan Kejahatan, Kencana, Ed 1, Cet 2 Jakarta,2008

Bunga Rampai Kebijakan Hukum Pidana (Perkembangan Penyusunan Konsep KUHP Baru), Jakarta Kencana, 2008

Pembaharuan Hukum Pidana Dalam Perspektif Kajian Perbandingan, PT Citra Aditya Bakti, Bandung, 2005

Frans Ceufin SVD, Hak-Hak Asasi Manusia :Pendasaran Dalam Filsafat Hukum dan Filsafat Politik, Yogyakarta, Titian Gilang Printika, 2008

H.R Abdussalam, Tanggapan Atas Rancangan Undang-Undang Tentang Hukum 
Acara Pidana, Restu Agung, Jakarta. 2008

Lilik Mulyadi, Hukum Acara Pidana (Suatu Tinjauan Khusus Terhadap Surat Dakwaan, Eksepsi, dan Putusan Peradilan), PT. Citra Aditya Bakti, Bandung, 2002.

Putusan Hakim Dalam Hukum Acara Pidana (Teori, Praktik, Teknik Penyusunan dan Permasalahannya), PT Citra Aditya Bakti, Bandung, 2007

M. Yahya Harahap, Pembahasan Permasalahan dan Penerapan KUHAP Pemeriksaan Sidang Pengadilan, Banding, Kasasi dan Peninjauan Kembali, Edisi Kedua, Jakarta, Sinar Grafika, 2000

M.Sofyan Lubis, Hak Tersangka Sebelum Pemeriksaan, Yogyakarta, Pustaka Yustisia, 2010

Majda El-Muntaj, Hak Asasi Manusia dalam Konstitusi Indonesia, Jakarta, Kencana Prenada Media Group, 2007

Muladi, Kapita Selekta Sistem Peradilan Pidana, Penerbit Universitas Diponogoro Semarang, 2002

Moch. Faisal Salam, HAM dalam Perspektif Sistem Peradilan Pidana dalam Hak Asasi Manusia, Hakekat Konsep dan Hukum dan Masyarakat, Refika Aditama, Bandung, 2007

Hukum Acara Pidana Dalam Teori dan Praktek, CV Mandar Maju, Bandung, 2001.

Nyoman Serikat Putra Jaya, Beberapa Pemikiran Kearah Pembangunan Hukum Pidana, PT Citra Aditya Bakti, Bandung, 2008

Penegakan Hukum dalam Era Reformasi, Relevansi Hukum Pidana Adat Dalam pembaharuan Hukum Pidana Nasional, PT. Citra Aditya Bakti, Bandung, 2005.

R. Soeparmono, Praperadilan dan Penggabungan Perkara Gugatan Ganti Kerugian dalam KUHAP, Mandar Maju, 2003

Rony Hanityo Soemitro, Penelitian Hukum dalam Praktek, Sinar Grafika, Jakarta, 2002

Sadjijono, Fungsi Kepolisian Dalam Pelaksanaan Good Governance, Laksbang, Yogyakarta, 2005

Sidik Sunaryo, Kapita Selekta Sistem Peradilan Pidana, UMM Press, Edisi Pertama, Cetakan Ketiga, Malang, 2005

Wasito Hadi Utomo, Hukum Kepolisian Di Indonesia, LPIP, Yogyakarta, 2002

\section{B. Peraturan Perundang - Undangan}

Republik Indonesia, Undang-Undang Nomor 8 Tahun 1981 tentang Hukum Acara Pidana, diundangkan di Jakarta pada tanggal 31 Desember 1981 dalam lembaran Negara R.I Tahun 1981 No.76, Pasal 1 Ayat (1) 